\title{
INTERPRETASI MAHKAMAH AGUNG TERHADAP ALASAN PEMBATALAN PUTUSAN ARBITRASE DALAM PASAL 70 UU NO. 30/1999
}

\author{
Ilhami Ginang Pratidina \\ ilhami.ginang@gmail.com \\ KJD Law Firm
}

\begin{abstract}
Article 70 of Law No. 30 of 1999 on Arbitration and Alternative Dispute Resolution (Law No. 30/1999) establish three basic reasons limitedly as cancellation of the arbitration decision. In the case of PT.Comarindo Express Tama Tour against Yemen Airways, the Supreme Court considers the court decision based on the elucidation and cancels the arbitration award on the grounds out of Article 70 of Law No. 30/1999. This paper seeks to elaborate on the interpretation of the Supreme Court against the cancellation reason arbitration award in terms of universal principles in the practice of modern arbitration and the legislation laws to use the statute approach, conceptual approach and case approach and suggests some court decision both Indonesian court and foreign court. The Supreme Court in this case misapplied the law due to the fact that consideration of the elucidation is in contrast to the universal principles in the practice of arbitration.
\end{abstract}

Keywords: arbitration, the reason for the cancellation decision.

\begin{abstract}
Abstrak
Pasal 70 Undang-Undang No. 30 Tahun 1999 tentang Arbitrase dan Alternatif Penyelesaian Sengketa (UU No. 30/1999) menetapkan tiga alasan limitatif sebagai dasar pembatalan putusan arbitrase. Dalam perkara PT. Comarindo Express Tama Tour melawan Yemen Airways, Mahkamah Agung mendasarkan pertimbangannya pada Penjelasan Umum UU No. 30/1999 dan membatalkan putusan arbitrase dengan alasan di luar ketentuan limitatif yang diatur dalam Pasal 70 UU tersebut. Tulisan ini mengelaborasi interpretasi Mahkamah Agung terhadap alasan pembatalan putusan arbitrase ditinjau dari prinsip universal dalam praktik arbitrase modern dan Hukum Perundang-Undangan dengan menggunakan statute approach, conceptual approach dan case approach serta mengemukakan beberapa putusan badan peradilan baik Indonesia maupun asing dalam memperkuat argumen. Mahkamah Agung dalam perkara tersebut telah salah menerapkan hukum karena mendasarkan pertimbangannya pada Penjelasan Umum yang substansinya bertentangan dengan batang tubuh dan prinsip universal dalam praktik arbitrase.
\end{abstract}

Kata Kunci: arbitrase, alasan pembatalan putusan. 


\section{Pendahuluan}

Putusan arbitrase bersifat final dan mengikat. Namun demikian,terhadap putusan tersebut masih dapat dimohonkan pembatalannya kepada pengadilan.Pasal 70 UU No. 30/1999 menetapkan tiga alasan yang dapat digunakan sebagai alasan permohonan pembatalan putusan arbitrase. Pasal 70 UU No. 30/1999 mengatur alasan limitatif pembatalan putusan arbitrase apabila putusan tersebut diduga mengandung unsur-unsur sebagai berikut: a) surat atau dokumen yang diajukan dalam pemeriksaan, setelah putusan dijatuhkan, diakui palsu atau dinyatakan palsu; b) setelah putusan diambil ditemukan dokumen yang bersifat menentukan, yang disembunyikan oleh pihak lawan; atau c) putusan diambil dari hasil tipu muslihat yang dilakukan oleh salah satu pihak dalam pemeriksaan sengketa. Ketentuan mengenai alasan pembatalan putusan arbitrase tersebut dinyatakan pula dalam Penjelasan Umum Alinea ke-18 UU No. 30/1999 pada BAB VII yang mengatur tentang pembatalan putusan arbitrase. Hal ini dimungkinkan karena beberapa hal, antara lain: a) surat atau dokumen yang diajukan dalam pemriksaan, setelah putusan dijatuhkan diakui palsu atau dinyatakan palsu; c) setelah putusan diambil ditemukan dokumen yang bersifat menentukan yang sengaja disembunyikan pihak lawan; atau c) putusan diambil dari hasil tipu muslihat yang dilakukan oleh salah satu pihak dalam pemeriksaan sengketa. Permohonan pembatalan putusan arbitrase diajukan kepada Ketua Pengadilan Negeri dan terhadap putusan Pengadilan Negeri tersebut hanya dapat diajukan permohonan banding ke Mahkamah Agung yang memutus dalam tingkat pertama dan terakhir.

Kedua pengaturan tersebut jelas memiliki implikasi yang berbeda, di mana dengan frase "sebagai berikut" dalam Pasal 70 UU No. 30/1999 menunjukkan sifat limitatif dari alasanalasan pembatalan putusan arbitrase, karena frase tersebut memiliki arti bahwa alasan yang dapat dijadikan dasar pembatalan putusan arbitrase terbatas pada alasan yang disebutkan dalam Pasal 70 UU No. 30/1999. Sedangkan, dengan adanya frase "antara lain" dalam Penjelasan Umum Alinea ke-18 tersebut, menimbulkan interpretasi bahwa alasan pembatalan putusan arbitrase tidak terbatas pada alasan yang diatur dalam Pasal 70 UU No. 30/1999. Frase "antara lain" memiliki makna yang identik dengan terminologi "inter alia" yang berarti "[a]mong other things" ${ }^{1}$ atau menyebut sebagian saja dari beberapa yang lain.

Yurisprudensi sebagai salah satu sumber hukum yang diakui di Indonesia sebagian besar memiliki penafsiran bahwa alasan pembatalan putusan arbitrase bersifat limitatif dengan mendasarkan diri pada ketentuan Pasal 70 UU No. 30/1999. Namun terdapat salah satu putusan Mahkamah Agung yang menyatakan sebaliknya, yakni Putusan Mahkamah Agung dalam perkara antara PT. Comarindo Expres Tama Tour \& Travel melawan Yemen Airways. ${ }^{2}$

Perkara ini mengenai pembatalan Putusan Arbitrase BANI Perwakilan Surabaya yang melibatkan PT Comarindo Express Tama Tour\&Travel (Pemohon Banding/ dahulu Termohon) dan Yemen Airways (Termohon dahulu Pemohon). Pemohon dan Termohon dalam sengketa

Bryan A. Garner (ed), 2009, Black's Law Dictionary, Edisi ke-9, West: Thomson Reuters, 2009, h. 883.

2 Putusan Mahkamah Agung Nomor 03/Arb.Btl/2005, perkara PT. Comarindo Expres Tama Tour \& Travel melawan Yemen Airways, 17 Mei 2006. 
ini terikat dalam dua perjanjian keagenan, yakni Appointment of General Sales Agent (GSA Passengers) tertanggal 29 Oktober 2001, dan Appointment of General Sales Agent (GSA Cargo) tertanggal 5 November 2002. Dalam pelaksanaannya, terjadi permasalahan hukum sehingga Pemohon mengajukan permohonan arbitrase terhadap Termohon melalui Badan Arbitrase Nasional Indonesia (BANI) Perwakilan Surabaya. BANI Perwakilan Surabaya kemudian menjatuhkan putusan arbitrase yang mengabulkan seluruh permohonan arbitrase Comarindo. ${ }^{3}$

Termohon tidak mengakui dan menyetujui putusan BANI Perwakilan Surabaya dan mengajukan permohonan pembatalan putusan tersebut ke Pengadilan Negeri Jakarta Selatan dengan mengemukakan alasan-alasan yang menjadi dasar pembatalan putusan arbitrase bahwa BANI Perwakilan Surabaya tidak memiliki yurisdiksi, kewenangan dan kompetensi untuk memeriksa dan memutus perkara karena berdasarkan perjanjian GSA Passengers dan GSA Cargo yang menjadi dasar sengketa antara para pihak tidak terdapat klausul arbitrase yang secara tegas memberikan kewenangan kepada BANI Perwakilan Surabaya untuk memeriksa dan memutus sengketa. Putusan BANI Perwakilan Surabaya adalah cacat hukum karena tidak didasarkan pada Pasal 1 angka 1 dan Pasal 19 ayat (1) UU No. 30/1999 yang intinya menyatakan bahwa pelaksanaan arbitrase harus didasarkan pada persetujuan para pihak, baik sebelum sengketa terjadi melalui klausul arbitrase maupun setelah sengketa terjadi melalui perjanjian arbitrase.

Alasan yang juga menjadi dasar pembatalan putusan arbitrasi adalah bahwa termohon telah mengirimkan surat-surat kepada BANI Perwakilan Surabaya Ref. No: BDR/VI/2004/048 tanggal 23 Juni 2004, Ref. No: BDR/VII/2004/054 tanggal 15 Juli 2004 dan Ref. No: BDR/ VII/2004/061 tanggal 26 Juni 2004 dimana ketiganya perihal penolakan penggunaan lembaga arbitrase, khususnya BANI Perwakilan Surabaya dalam penyelesaian sengketa, akan tetapi BANI Perwakilan Surabaya tetap menjalankan proses persidangan. Dengan tetap berjalannya proses persidangan oleh BANI Perwakilan Surabaya sampai ditetapkannya putusan arbitrase, yang seharusnya BANI Perwakilan Surabaya tidak memiliki kewenangan dalam menyelesaikan perkara tersebut menunjukkan adanya suatu tipu muslihat sebagaimana diatur dalam Pasal 70 UU No. 30/1999 yang sengaja dilakukan oleh Pemohon dengan berbagai cara dan alasan untuk tercapainya suatu putusan yang dimohonkan oleh Pemohon kepada BANI Perwakilan Surabaya.

Pemohon kemudian mengajukan eksepsi dengan dalil bahwa permohonan pembatalan putusan arbitrase oleh Termohon bertentangan dengan syarat yang ditentukan dalam Pasal 70 UU No. 30/1999, dimana dalil Termohon bukan alasan yang dapat digunakan untuk membatalkan putusan arbitrase sebagaimana diatur dalam Pasal 70 UU No. 30/1999. Selain itu, alasan adanya tipu muslihat tersebut harus dibuktikan dengan putusan yang berkekuatan hukum tetap, sebagaimana diatur dalam Penjelasan Pasal 70 UU No. 30/1999. Terhadap permohonan pembatalan putusan dan eksepsi tersebut, Pengadilan Negeri Jakarta Selatan ${ }^{4}$ memutuskan sebagai berikut: 1) Menolak eksepsi Pemohon; 2) Mengabulkan permohonan Termohon; 3)

3 Putusan Badan Arbitrase Nasional Indonesia Nomor 15/ARB/BANI JATIM/III/2004, perkara Comarindo Express Tama\&Tour melawan Yemen Airways, 19 Agustus 2004.

4 Putusan Pengadilan Negeri Jakarta Selatan, No. 254/Pdt.P/2004/PN.Jat.Sel, 6 Januari 2005. 
Membatalkan Putusan Arbitrase dari BANI Perwakilan Surabaya No. 15/ARB/BANI JATIM/ III/2004 tanggal 19 Agustus 2004; dan 4) Menghukum Pemohon untuk membayar biaya perkara sebesar Rp. 194.000 (seratus sembilan puluh empat ribu rupiah)

Pemohon kemudian mengajukan Permohonan Banding atas putusan Pengadilan Negeri Jakarta Selatan tersebut ke Mahkamah Agung.Dalam memori bandingnya, Pemohon menyatakan bahwa Majelis Hakim Pengadilan Negeri Jakarta Selatan telah salah menerapkan hukum. Bahwa alasan pembatalan yang memenuhi syarat telah dirinci secara "limitatif" dalam Pasal 70 UU No. 30/1999.Sehingga, di luar alasan dalam Pasal 70 tersebut, permohonan pembatalan dianggap tidak mempunyai dasar hukum. Selain itu, Termohon juga tidak dapat membuktikan adanya tipu muslihat yang menjadi alasan permohonan pembatalan putusan BANI Perwakilan Surabaya tersebut.Sesuai dengan Penjelasan Pasal 70 UU No. 30/1999, alasan tipu muslihat yang menjadi alasan permohonan pembatalan putusan arbitrase harus dibuktikan dengan putusan pengadilan (pidana) yang telah berkekuatan hukum tetap. Dengan demikian, sudah seharusnya permohonan pembatalan putusan arbitrase BANI tidak dapat dapat diterima.

Berdasarkan alasan-alasan permohonan Banding tersebut, Majelis Hakim Mahkamah Agung dalam tingkat Banding berpendapat bahwa Pengadilan Negeri Jakarta Selatan tidak salah menerapkan hukum, bahkan menambah dan memperbaiki pertimbangan hukumnya dengan menyatakan bahwa alasan pembatalan putusan arbitrase sebagaimana diatur dalam Pasal 70 UU No. 30/1999 tidak bersifat limitatif. Dalam penjelasan umum Undang-Undang Nomor 30 Tahun 1999 tertera bahwa kata 'antara lain' pada penjelasan memungkinkan Pemohon untuk mengajukan permohonan pembatalan putusan arbitrase atas alasan di luar yang tertera dalam Pasal 70 UU No. 30/1999, seperti halnya dengan alasan kompetensi absolut yang dikemukakan oleh Pemohon. ${ }^{5}$

Lebih lanjut Majelis Hakim mempertimbangkan bahwa, dalam Pasal 23 perjanjian GSA Passanger dan Pasal 24 perjanjian GSA Cargo tidak menyatakan secara tegas forum arbitrase mana yang dipilih oleh para pihak. Dalam perjanjian tersebut hanya terdapat klausul yang menyatakan pada sub bab Arbitration: This Agreement shall in all respect be interpreted in accordance with the law of the Republic of Yemen. Klausul tersebut menunjukkan bahwa penyelesaian sengketa dari perjanjian-perjanjian tersebut harus diselesaikan berdasarkan Hukum Republik Yaman. Oleh sebab itu, BANI Perwakilan Surabaya tidak berwenang untuk menyelesaikan sengketa tersebut.Dengan demikian, permohonan pembatalan putusan BANI Perwakilan Surabaya dapat dikabulkan dengan alasan BANI Perwakilan Surabaya tidak memiliki kompetensi absolut untuk memeriksa dan memutus perkara yang bersangkutan.

Berdasarkan pertimbangan-pertimbangan tersebut, Majelis Hakim Mahkamah Agung dalam tingkat Banding memutuskan untuk menolak permohonan Banding yang diajukan Pemohon dan memperbaiki putusan Pengadilan Negeri Jakarta Selatan sehingga berbunyi: 1) Menolak eksepsi Pemohon; 2) Mengabulkan permohonan Termohon; 3) Membatalkan

5 Putusan Mahkamah Agung Republik Indonesia Nomor 03/Arb.Bt1/2005, perkara PT. Comarindo Expres Tama Tour \& Travel, h. 20. 
Putusan Arbitrase BANI Perwakilan Surabaya No. 15/ERB/BANI JATIM/III/2004 tanggal 19 Agustus 2004; 4) Menyatakan BANI Perwakilan Surabaya tidak berwenang untuk memeriksa dan memutus sengketa antara Pemohon dan Termohon yang didasarkan pada perjanjian GSA Passengers dan perjanjianGSA Cargo; dan 5) Menghukum Pemohon untuk membayar biaya perkara dalam kedua tingkat peradilan, yang dalam tingkat Banding ini ditetapkan sebesar Rp. 500.000 (lima ratus ribu rupiah).

Berdasarkan pertimbangan Mahkamah Agung dalam perkara ini, terlihat bahwa interpretasi Mahkamah Agung terhadap ketentuan Pasal 70 UU No. 30/1999 mengenai alasan-alasan pembatalan putusan arbitrase tidak bersifat limitatif. Terdapat alasan lain di luar ketiga alasan sebagaimana disebutkan dalam Pasal 70 UU No. 30/1999 yang dapat digunakan sebagai dasar pembatalan putusan arbitrase, yang dalam perkara ini adalah alasan tidak adanya kewenangan absolut bagi lembaga arbitrase untuk menyelesaikan perkarayang diakui sebagai alasan pembatalan putusan arbitrase.

Putusan tersebut bertolak belakang dengan putusan Mahkamah Agung lainnya, dimana sebagian besar putusan Mahkamah Agung menafsirkan ketentuan Pasal 70 UU No. 30/1999 sebagai ketentuan yang bersifat limitatif. Misalnya dalam putusan Mahkamah Agung dalam perkara antara PT. Padjajaran Indah Prima melawan PT. Pembangunan Perumahan. ${ }^{6}$ Perkara ini mengenai pembatalan putusan Badan Arbitrase Nasional Indonesia (BANI) Perwakilan Bandung yang melibatkan PT Padjajaran Indah Prima (Pemohon Banding/ dahulu Termohon) dan PT Pembangunan Perumahan (Termohon/ dahulu Pemohon).Hal yang menjadi pokok perkara adalah perihal wanprestasi terhadap Perjanjian Pemborongan Pekerjaan Pembangunan Gedung Plaza Padjajaran yang dituangkan pada Surat Perjanjian Borongan No. 02/SPP/DUPIP/VI/2006 tanggal 21 Juni 2006.

Pemohon mengajukan perkara tersebut ke BANI Perwakilan Bandung yang kemudian oleh BANI Perwakilan Bandung, perkara tersebut diputus melalui Putusan No. 03/2007/BANI BANDUNG dengan amar putusannya dalam Konvensi menyatakan Termohon Konvensi (PT Pembangunan Perumahan) telah ingkar janji (wanprestasi) kepada Pemohon Konvensi. Kemudian dalam rekonvensi: 1) Menyatakan Termohon Konvensi/Pemohon Rekonvensi memiliki kewajiban yang harus dibayar kepada Pemohon Konvensi/ Termohon Rekonvensi sebesar Rp.1.750.000.000,- (satu miliar tujuh ratus lima puluh juta rupiah); 2) Menghukum Termohon Konvensi/Pemohon Rekonvensi untuk membayar kewajibannya kepada Pemohon Konvensi/Termohon Rekonvensi sebesar Rp.1.750.000.000,- (satu miliar tujuh ratus lima puluh juta rupiah), yang harus dibayar oleh Termohon Konvensi/Pemohon Rekonvensi selambat lambatnya dalam waktu 30 (tiga puluh) hari sejak Putusan Arbitrase didaftarkan di Kepaniteraan Pengadilan Negeri Kelas IA Bandung. ${ }^{7}$ Termohon kemudian mengajukan permohonan pembatalan terhadap putusan arbitrase tersebut ke Pengadilan Negeri Sumedang

6 Putusan Mahkamah Agung Republik Indonesia Nomor 729 K/Pdt.Sus/2008, perkara PT Padjajaran Indah Prima melawan PT Pembangunan Perumahan, 30 Maret 2009.

7 Ibid, h. 8-9. 
dengan salah satu alasan bahwa putusan BANI Perwakilan Bandung tidak memenuhi prosedur yang benar karena tidak didaftarkan ke Pengadilan Negeri sesuai dengan jangka waktu yang ditetapkan dalam Pasal 59 UU No. 30/1999, sehingga putusan BANI harus dibatalkan. Secara garis besar, Termohon (PT Pembangunan Perumahan)mendalilkan bahwa Pasal 70 UU No. 30/1999 tidak bersifat limitatif karena adanya frasa "antara lain" dalam Penjelasan Umum alenia ke-18 UU No. 30/1999, sehingga dimungkinkan pembatalan putusan arbitrase dilakukan berdasarkan alasan-alasan lain di luar yang tercantum dalam Pasal 70 UU No. 30/1999.

Terhadap gugatan tersebut, Pengadilan Negeri Sumedang memutus dalam Putusan No. 10/Pdt.G/2008/PN.Smd tanggal 12 Juni 2008 dengan amar putusan sebagai berikut: 1) Menerima dan mengabulkan permohonan Termohon (PT Pembangunan Perumahan) untuk sebagian; 2) Menyatakan Putusan BANI Perwakilan Bandung No. 03/2007/BANI BANDUNG tanggal 17 Maret 2008 tidak berkekuatan hukum; 3) Membatalkan Putusan BANI Perwakilan Bandung No. 03/2007/BANI BANDUNG tanggal 17 Maret 2008.

Pemohon kemudian mengajukan Banding ke Mahkamah Agung dengan alasan bahwa Pengadilan Negeri Sumedang telah salah menerapkan hukum karena alasan pembatalan putusan arbitrase telah diatur secara "limitatif" dalam Pasal 70 UU No. 30/1999. Sehingga alasan di luar ketentuan limitatif tersebut tidak dapat diterima. Alasan Pemohon tersebut dibenarkan oleh Mahkamah Agung yang dalam pertimbangannya menyatakan bahwa judex facti yang membatalkan putusan BANI a-quo tanpa memenuhi syarat-syarat yang diatur dalam Pasal 70 Undang-Undang No.30 Tahun 1999 telah salah menerapkan hukum. Sebab alasan pembatalan putusan Arbitrase sebagaimana diatur dalam Pasal 70 Undang-Undang No.30 Tahun 1999 tentang Arbitrase dan Alternatif Penyelesaian Sengketa tersebut telah dirinci secara limitatif 8. Kemudian Mahkamah Agung mengadili sendiri dengan amar putusan: 1) Mengabulkan permohonan banding dari Pemohon (PT Padjajaran Indah Prima); 2) Membatalkan putusan Pengadilan Negeri Sumedang No. 1/Pdt.G/2008/PN.Smd. tanggal 12 Juni 2008; 3) Menguatkan putusan BANI Perwakilan Bandung No. 03/2007/BANI BANDUNG tanggal 17 Maret 2008 baik dalam Konvensi maupun dalam Rekonvensi.

Berdasarkan penjabaran di atas, pertimbangan Mahkamah Agung dalam putusan tersebut merefleksikan interpretasi Mahkamah Agung terhadap sifat limitatif alasan pembatalan putusan sebagaimana diatur dalam Pasal 70 UU No. 30/1999. Oleh karena itu tidak dimungkinkan untuk mengajukan alasan lain di luar Pasal 70 UU No. 30/1999 seperti halnya yang didalilkan Termohon (PT Pembangunan Perumahan) dalam perkara tersebut.

Selain itu, putusan Mahkamah Agung dalam perkara antara Badan Arbitrase Nasional Indonesia (BANI) melawan PT Cipta Kridatama dan Bulk Trading, SA ${ }^{9}$ juga merupakan salah satu putusan yang memiliki penafsiran bahwa ketentuan Pasal 70 UU No. 30/1999 bersifat limitatif. Perkara ini mengenai permohonan pembatalan putusan arbitrase BANI yang

$8 \quad$ Ibid, h. 47.

9 Putusan Badan Arbitrase Nasional Nomor 369 K/Pdt.Sus/2010 perihal PT Cipta Kridatama dan Bulk Trading, 9 Juni 2010. 
melibatkan tiga pihak, yakni BANI (Pemohon Banding/ dahulu Termohon), PT Cipta Kridatama (Termohon Banding/ dahulu Pemohon) dan Bulk Trading, SA (Turut Termohon Banding/ dahulu Turut Termohon).Termohon dan Turut Termohon telah menandatangani perjanjian kegiatan penambangan batubara yang dituangkan dalam Kontrak Pekerjaan Penambangan Batubara No. 01/CK-BT/KON TAMB/XII/2006 tertanggal 20 Februari 2007. Berdasarkan kontrak tersebut, pekerjaan penambangan akan dilakukan Termohon dalam jangka waktu 60 bulan atau apabila sudah tercapai target produksi 5,7 juta MT (metric ton).

Dalam perjalanannya, kontrak tersebut mengalami permasalahan hukum dan untuk menyelesaikan permasalahan tersebut, Termohon mengajukan permohonan arbitrase terhadap Turut Termohon melalui BANI (Pemohon) dengan mendalilkan bahwa Turut Termohon telah melakukan wanprestasi. Terhadap permohonan tersebut, Majelis Arbitrase memberikan Putusan Arbitrase No. 300/II/ARB-BANI/2009 tertanggal 2 Oktober 2009 yang amarnya menyatakan menolak Permohonan Arbitrase Pemohon dalam Konvensi (PT Cipta Kridatama) dan menerima Permohonan Rekonvensi Termohon (Bulk Trading, SA) serta menyatakan Pemohon telah melakukan wanprestasi.

Termohon (PT Cipta Kridatama) kemudian mengajukan permohonan pembatalan putusan arbitrase tersebut ke Pengadilan Negeri Jakarta Selatan dengan alasan diantaranya: 1) Pembacaan putusan arbitrase melebihi jangka waktu sebagaimana diatur dalam Pasal 57 UU No. 30/1999. Berdasarkan Pasal 57 UU No. 30/1999, seharusnya putusan arbitrase dibacakan paling lambat tanggal 19 Oktober 2009, namun nyatanya putusan tersebut baru dibacakan pada 22 Oktober 2009; 2) Putusan arbitrase melanggar kepatutan dan keadilan sebagaimana diatur dalam Pasal 56 ayat (1) UU No. 30/1999, karena Majelis Arbitrase tidak mempertimbangkan dalil dan bukti yang diajukan Termohon, khususnya menyangkut kewajiban Turut Termohon untuk melakukan pembayaran atas pekerjaan yang telah dilakukan oleh Termohon.

Terhadap permohonan pembatalan putusan BANI tersebut, Pengadilan Negeri Jakarta Selatan mengambil penetapan No. 270/Pdt.P/2009/PN.Jkt.Sel.tanggal 4 Januari 2010 yang amarnya sebagai berikut: 1) Mengabulkan permohonan Termohon (PT Cipta Kridatama) untuk seluruhnya; 2) Menatakan batal demi hukum Putusan Arbitrase BANI No. 300/II/ARBBANI/2009 tanggal 22 Oktober 2009; 3) Memerintahkan Pemohon (BANI) untuk memeriksa kembali sengketa antara Termohon dan Turut Termohon berkaitan dengan Kontrak Pekerjaan Penambangan Batubara No. 01/CK-BT/KON-TAMB/XII/2006 tertanggal 20 Februari 2007 dengan Arbiter lain, tanpa mengenakan atau mewajibkan pembayaran biaya perkara dan biaya lainnya dari para pihak; 4) Memerintahkan Turut Termohon untuk tunduk dan taat pada Penetapan ini; 5) Memerintahkan Panitera Pengadilan Negeri Jakarta Selatan untuk mencoret dari register yang ada pada Kepaniteraan Pengadilan Negeri Jakarta Selatan tentang pendaftaran atas Putusan Badan Arbitrase Nasional Indonesia No. 300/II/ARB-BANI/2009 tanggal 22 Oktober 2009; 6) Menghukum Pemohon (BANI) untuk membayar biaya perkara dalam perkara ini sebesar Rp. 379.000 (tiga ratus tujuh puluh sembilan ribu rupiah) 
Pemohon kemudian mengajukan Permohonan Banding atas Penetapan tersebut ke Mahkamah Agung dengan alasan, bahwa alasan yang digunakan Termohon dalam permohonan pembatalan putusan arbitrase di luar ketentuan Pasal 70 UU No. 30/1999, sehingga tidak memenuhi syarat pembatalan putusan arbitrase. Pasal 56 dan Pasal 57 UU No. 30/1999 yang dijadikan alasan pembatalan putusan arbitrase bukan merupakan syarat pembatalan putusan arbitrase karena tidak memiliki sanksi pembatalan putusan arbitrase.

Terhadap alasan Pemohon tersebut, Mahkamah Agung sependapat dengan menyatakan bahwa Pengadilan Negeri Jakarta Selatan telah salah menerapkan hukum.

Perkara ini adalah merupakan permohonan pembatalan putusan arbitrase, tetapi permohonan pembatalan putusan arbitrase mendasarkan permohonannya pada Pasal 54 dan Pasal 57 UU No. 30/1999; bahwa Pasal 54 dan 57 UU No. 30/1999, tidak memuat sanksi batalnya putusan; bahwa satu-satunya pasal yang mengatur tentang pembatalan putusan arbitrase ada pada Pasal 70 UU No. 30/1999,...; ...; bahwa dengan demikian Penetapan Pengadilan Negeri Jakarta Selatan No. 270/Pdt.P/2009/ PN.Jkt.Sel. tanggal 4 Januari 2010 salah dan harus dibatalkan. ${ }^{10}$ (cetak tebal oleh penulis)

Berdasarkan pertimbangan tersebut, Mahkamah Agung memberikan putusan dengan amar sebagai berikut: 1) Menerima permohonan banding dari Pemohon (BANI); 2) Membatalkan Penetapan Pengadilan Negeri Jakarta Selatan No. 270/Pdt.P/PN.Jkt.Sel tanggal 4 Januari 2010; 3) Mengadili sendiri: menolak permohonan pembatalan putusan arbitrase dari Termohon (PT Citra Kridatama).

Pertimbangan putusan Mahkamah Agung tersebut menunjukkan bahwa ketentuan Pasal 70 UU No. 30/1999 bersifat limitatif.Artinya, alasan di luar ketentuan Pasal 70 tersebut tidak dapat diterima sebagai alasan pembatalan putusan arbitrase. Selain kedua putusan terakhir di atas, masih terdapat beberapa putusan Mahkamah Agung yang memiliki kaidah hukum identik yang menyatakan bahwa ketentuan Pasal 70 UU No. 30/1999 merupakan ketentuan yang bersifat limitatif, sebagai contoh adalah Putusan Mahkamah Agung dalam perkara antara PT. Aneka Bina Lestari melawan Cristian Handoko ${ }^{11}$ dan Putusan Mahkamah Agung dalam perkara antara PT. Manunggal Engineering melawan Badan Arbitrase Nasional Indonesia (BANI), PT. Multi Adverindo, PT. Geostructure Dynamics. Putusan Mahkamah Agung dalam perkara antara PT. Aneka Bina Lestari melawan Cristian Handoko memuat kaidah hukum sebagai berikut:

Putusan Pengadilan Negeri Jakarta Pusat No. 2/P/Pembatalan Arbitrase/ 2009/PN.Jkt. Pst., tanggal 10 November 2009 tidak mengandung unsur Pasal 70 UU No. 30 Tahun 1999;..., bahwa berdasarkan pertimbangan di atas, maka permohonan peninjauan kembali yang diajukan oleh Pemohon Peninjauan Kembali: PT ANEKA BINALESTARI tersebut harus ditolak; ${ }^{12}$ (cetak tebal oleh penulis)

Putusan ini menguatkan putusan sebelumnya, yakni Putusan Mahkamah Agung No. 65 K/Pdt. Sus/2010 tanggal 11 Mei 2010 yang membatalkan putusan Pengadilan Negeri Jakarta Pusat

10 Ibid, h. 27-28.

11 Putusan Mahkamah Agung Republik Indonesia Nomor 44 PK/Pdt.Sus/2011 perihal perkara PT Aneka Bina Lestari melawan Cristian Handoko, 12 April 2012.

$12 \quad$ Ibid, h. 31-31. 
No. 2/P/Pembatalan Arbitrase/2009/PN.Jkt.Pst. tanggal 10 November 2009, karenamenerima permohonan pembatalan putusan arbitrase BANI yang diajukan oleh Pemohon dan membatalkan putusan arbitrase BANI dengan dasar alasan pembatalan putusan arbitrase di luar ketentuan Pasal 70 UU No. 30/1999,yakni alasan bahwa putusan BANI diambil tidak berdasarkan hukum karena melanggar yurisprudensi tentang uang paksa.

Putusan Mahkamah Agung dalam perkara antara PT. Manunggal Engineering melawan Badan Arbitrase Nasional Indonesia (BANI), PT. Multi Adverindo, PT. Geostructure Dynamics ${ }^{13}$ memuat kaidah hukum bahwa alasan-alasan banding yang diajukan oleh oleh Pemohon Banding tidak dapat dibenarkan, karena Judex Facti tidak salah dalam menerapkan hukum, pertimbangannya sudah tepat dan benar. ${ }^{14}$ Dalam hal ini, Putusan Mahkamah Agung menguatkan Putusan Pengadilan Negeri Jakarta Pusat No. 36/Pdt.G/2011/PN.Jkt.Pst, tanggal 8 Juni 2011 yang menolak permohonan pembatalan putusan arbitrase BANI yang diajukan oleh Pemohon Banding karena salah satu alasan permohonan pembatalan putusan arbitrase yang diajukan Pemohon di luar ketentuan Pasal 70 UU No. 30 Tahun 1999, yakni berkaitan dengan pengangkatan Ir. H. Agus Kartasasmita, MSc., MT., FCBArb. sebagai Ketua Majelis Arbitrase. ${ }^{15}$

Tulisan ini berusaha mengkaji pertimbangan Mahkamah Agung dalam perkara PT. Comarindo Expres Tama Tour \& Travel melawan Yemen Airways terkait dengan alasan pembatalan putusan arbitrase sebagaimana diatur dalam Pasal 70 UU No. 30/1999 dan Penjelasan Umum Alenia ke-18 UU No. 30/1999, dimana permasalahan yang diangkat dalam tulisan ini adalah: 1) Bagaimanakah pertimbangan Mahkamah Agung dalam perkara antara PT. Comarindo Expres Tama Tour \& Travel melawan Yemen Airways ditinjau dari prinsip yang dianut secara universal dalam praktik arbitrase modern?; 2) Bagaimanakah kedudukan Penjelasan Umum Alenia ke-18 UU No. 30/1999 yang digunakan sebagai dasar pertimbangan Mahkamah Agung dalam perkara antara PT. Comarindo Expres Tama Tour \& Travel melawan Yemen Airways ditinjau dari hukum perundang-undangan? Sehingga, dapat diketahui ketentuan manakah yang seharusnya dijadikan dasar oleh Mahkamah Agung dalam memutus perkara pembatalan putusan arbitrase.Dengan demikian, inkonsistensi interpretasi Mahkamah Agung dalam menafsirkan ketentuan Pasal 70 UU No. 30/1999 dapat dihindari.

\section{Alasan Pembatalan Putusan Arbitrase Bersifat Limitatif}

Dalam praktik arbitrase modern, pembatasan alasan pembatalan putusan arbitrase oleh undang-undang telah diakui sebagai prinsip yang universal, ${ }^{16}$ karena pembatalan putusan

\footnotetext{
13 Putusan Mahkamah Agung Republik Indonesia Nomor 770 K/Pdt.Sus/2011 perihal perkara PT. Manunggal Engineering melawan Badan Arbitrase Nasional Indonesia (BANI), PT. Multi Adverindo, PT. Geostructure Dynamics, Sus/2011, 19 Maret 2012.

14 Ibid, h. 23.

15 Ibid, h. 20.

16 Philippe Fouchard, et.al.,Faouchard, Gaillard, Goldman on International Commercial Arbitration, Dordrecht, The Netherlands: Kluwer Law International, 1999, h. 926.
} 
arbitrase dapat melukai perasaan pihak yang beritikad baik, melukai perasaan arbiter yang memutus sengketa, serta melahirkan keraguan bagi masyarakat, baik di dalam maupun di luar negeri, terhadap arbitrase di Indonesia. Oleh karena itu, pembatalan putusan arbitrase hanya dapat dilakukan terhadap hal-hal fundamental yang diatur oleh undang-undang. ${ }^{17}$ Prinsip tersebut telah diakomodir dalam Article V Konvensi New York 1958 yang menyatakan bahwa,

Recognition and enforcement of the award may be refused, at the request of the party against whom it is invoked, only if that party furnishes to the competent authority where the recognition and enforcement is sought, proof that: a) The parties to the agreement referred to in article II were, under the law applicable to them, under some incapacity, orthe said agreement is not valid under the law to which theparties have subjected it or, failing any indication thereon, under the law of the country where the award was made; or b) The party against whom the award is invoked was notgiven proper notice of the appointment of the arbitrator or ofthe arbitration proceedings or was otherwise unable topresent his case; or c) The award deals with a difference not contemplated by ornot falling within the terms of the submission to arbitration, orit contains decisions on matters beyond the scope of thesubmission to arbitration, provided that, if the decisions onmatters submitted to arbitration can be separated from thosenot so submitted, that part of the award which containsdecisions on matters submitted to arbitration may berecognized and enforced; or d) The composition of the arbitral authority or the arbitralprocedure was not in accordance with the agreement of theparties, or, failing such agreement, was not in accordancewith the law of the country where the arbitration took place;or e) The award has not yet become binding on the parties, orhas been set aside or suspended by a competent authority ofthe country in which, or under the law of which, that awardwas made.

Ketentuan Article V Konvensi New York 1958 tersebut identik dengan ketentuan dalam Article 34 (2) UNCITRAL Model Law, ${ }^{18}$ walaupun Konvensi New York 1958 tidak secara tegas mengatur masalah pembatalan, melainkan lebih kepada pengaturan alasan penolakan pengakuan dan pelaksanaan putusan arbitrase asing.Pengaturan yang demikian dalam Konvensi New York 1958 kemungkinan disebabkan karena Konvensi New York 1958 menganut sistem Anglo Saxon yang tidak mengenal upaya hukum membatalkan suatu putusan badan peradilan (dalam hal ini putusan badan arbitrase). Upaya yang disediakan adalah upaya permohonan peninjauan atau revisi terhadap putusan. ${ }^{19}$ Selanjutnya Article 34 UNCITRAL Model Law menyatakan bahwa:

(2) An arbitral award may be set aside by the court specified in article 6 only if:

a. the party making the application furnishes proof that: (i) a party to arbitration agreement referred to in article 7 was under incapacity; or the said agreement is not valid under the law to which the parties have subjected it, or failing indication thereon, under the law of this State; or (ii) the party making the application was not given proper notice of the appointment of an arbitrator or of the arbitral proceedings or was otherwise unable to present

17 Sujayadi, "Patologi dalam Arbitrase Indonesia: Ketentuan Pembatalan Putusan Arbitrase dalam Pasal 70 UU No. 30/1999, artikel ilmiah, h. 13.

18 Ibid, h. 12.

19 Badan Pembinaan Hukum Nasional Departemen Hukum dan HAM, Analisis dan Evaluasi Hukum Penyelesaian Sengketa Melalui Arbitrase (Undang-Undang Nomor 30 Tahun 1999), Badan Pembinaan Hukum Nasional Departemen Hukum dan HAM, Jakarta, 2006, h. 47. 
his case; or (iii) the award deals with a dispute not contemplated by or not falling within the terms of the submission to arbitration, or contains decisions on matters beyond the scope of the submission to arbitration, provided that, if the decisions on matters submitted to arbitration can be separated from those not so submitted, only that part of the award which contains decisions on matters not submitted to arbitration may be set aside; or (iv)the composition of the arbitral tribunal or the arbitral procedure was not in accordance with the agreement of the parties, unless such agreement was in conflict with a provision of this Law from which the parties cannot derogate, or, failing such agreement, was not in accordance with this Law; or

b. the court finds that: (i) the subject-matter of the dispute is not capable of settlement by arbitration under the law of this State; or (ii) the award is in conflict with the public policy of this State. (cetak tebal oleh penulis)

baik Article V Konvensi New York 1958 maupun Article 34 (2) UNCITRAL Model Law, keduanya menggunakan frase "only if" yang menunjukkan bahwa Konvensi New York 1958 dan UNCITRAL Model Law menghendaki adanya pembatasan terhadap alasan pembatalan putusan arbitrase.

International Center for the Settlement of Investment Disputes (ICSID) dalam konvensinya juga menerapkan pembatasan alasan-alasan pembatalan putusan arbitrase.ICSID merupakan Badan Arbitrase yang memiliki kewenangan khusus dan terbatas pada sengketa penanaman modal asing. Kompetensi absolut ICSID tersebut diatur dalam Article 25 Konvensi ICSID yang menyatakan bahwa ICSID tidak menyelesaikan sengketa antar subjek hukum perdata, namun menyelesaikan sengketa antar pemerintah suatu negara sebagai subjek hukum publik yang mengeluarkan izin terkait dengan investasi dan investor asing sebagai subjek hukum perdata.

Kedudukan hukum (legal standing) para pihak yang dapat berperkara di ICSID adalah "between a Contracting State (or any constituent subdivision or agency of a Contracting State designated to the Centre by that State) and a national of another Contracting State", yakniantara negara peserta Konvensi ICSID dengan warga negaradari negara peserta konvensi ICSID lainnya, di mana kedua subyek yang bersengketa tersebut harus telah meratifikasi konvensi ICSID sebagai keanggotaan dari International Bank for Reconstruction and Development (World Bank).Dengan demikian, parapihak yang dapat berkara di ICSID adalah: 1) Negara penerima investasi (host state) dengan investor asing (natuurlijk persoon); dan/ atau 2) Negara penerima investasi (host state) dengan badan hukum asing (recht persoon)yangberinvestasi di negara penerima investasi; dan/ atau 3) Negara penerima investasi (host state) dengan badan hukum (recht persoon) yang didirikan di negara penerima investasi, namunsahamnya sebagian besar dimiliki pihak asing atau dikuasai pihak asing, sehingga harus diperlakukan sebagai badan hukum asing. Selain itu, disyaratkan pula bahwa untuk dapat berperkara di ICSID harus ada pernyataan tertulis berupa kesepakatan dari para pihak yang bersengketa, mengenai klausul penyelesaian sengketa yang menunjuk ICSID sebagai lembaga penyelesaian sengketa. 
Berbeda dengan konvensi lainnya yang umumnya menyerahkan kewenangan pembatalan putusan arbitrase pada pengadilan nasional, Konvensi ICSID mengatur bahwa pembatalan putusan ICSID tidak dapat dibatalkan melalui pengadilan nasional melainkan melalui permohonan ke Sekretariat Jenderal ICSID. ${ }^{20}$ Alasan-alasan pembatalan putusan ICSID sendiri diatur dalam Article 52 ayat (1) yang menyatakan bahwa,

Either party may request annulment of the award by an application in writing addressed to the Secretary-General on one or more of the following grounds: a. That the Tribunal was not properly constituted; $b$. That the Tribunal has manifestly exceeded its powers; $c$. That there was corruption on the part of a member of the Tribunal; $d$. That there has been a serious departure from a fundamental rule of procedure; e. That the award has failed to state the reasons on which it is based. (cetak tebal oleh penulis)

frasa "one or more of the following grounds" menyiratkan bahwa alasan yang dapat diajukan sebagai dasar permohonan pembatalan putusan arbitrase hanya alasan yang diatur dalam artikel tersebut.

Salah satu putusan ICSID terkait pembatalan putusanarbitrase dapat ditemui dalam perkara Impregilo S.p.A. v. Argentine Republic. ${ }^{21}$ Perkara ini melibatkan Impregilo, suatu perusahaan Italia yang menjadi pemegang saham minoritas di AGBA, sebuah perusahaan Argentina yang beroperasi memberikan pelayanan penyediaan dan sanitasi air dan Pemerintah Provinsi Buenos Aires, Argentina.Pada tahun 1999, Impregilo meningkatkan investasinya setelah mengetahui AGBA telah memperoleh izin dan membuat kontrak dengan Pemerintah Provinsi Buenos Aires, Argentina.Akan tetapi, pada tahun 2006, pemerintah provinsi tersebut membatalkan kontrak dengan AGBA secara sepihak dan menyerahkan pekerjaan tersebut ke badan milik negara. Keadaan tersebut mengakibatkan kerugian bagi Impregilo, sehingga Impregilo mengajukan perkara tersebut ke ICSID dengan dasar bahwa Argentina telah melanggar Investment treaties:Argentina-Italy BIT.

ICSID memutuskan bahwa Pemerintah Argentina bersalah dan wajib membayar ganti rugi kepada Impregilo sebesar US\$ 12 juta ditambah bunga sebagai kompensasi.Pemerintah Argentina yang tidak menerima putusan tersebut kemudian mengajukan pembatalan putusan tersebut ke Sekretariat ICSID dengan dasar bahwa ICSID tidak memiliki kewenangan karena dalam Argentina-Italy BIT terdapat klausul MFN (Most-Favoured Nation) pada Article 8 sebagai berikut:

1. Any dispute relating to an investment between an investor ofone of the Contracting Parties and the other Party, arising out of orrelating to this Agreement, shall, to the extent possible, be settledthrough friendly consultation between the parties to the dispute;

2. If the dispute cannot be settled amicably, it may be submitted tothe competent judicial or administrative courts of the Party in whoseterritory the investment is made.

3. Where after eighteen months from the date of notice ofcommencement of proceedings

20 Sudargo Gautama, Indonesia dan Konvensi-Konvensi Hukum Perdata Internasional, Bandung: Alumni, 2005, h. 267.

21 Impregilo S.p.A. v. Argentine Republic, ICSID, No.ARB/07/17, Decision of the ad hoc Committee on the Application for Annulment, 24 Januari 2014 dan Award, 21 Juni 2011. 
before the courts mentioned in paragraph 2 above, the dispute between an investor and one of theContracting Parties has not been resolved, it may be referred to international arbitration

Sehingga sebelum diajukan ke ICSID, seharusnya perkara tersebut diajukan terlebih dahulu ke pengadilan nasional.Dengan demikian, ICSID melampaui kewenangannya dan putusan dapat dibatalkan sebagaimana diatur dalam Article 52 ayat (2) Konvensi ICSID.

Dalam pertimbangannya, ICSID menyatakan bahwa. annulment is an essential but exceptional remedy. It is well understood that the grounds listed in Article 52(1) are the only

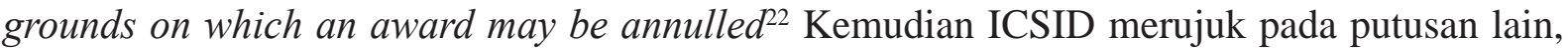
yakni putusan dalam perkara Manifezzini (Argentine investor) v. Spain, dan putusan dalam perkara Siemens (German investor) v. Argentina, kemudian menyatakan bahwa adanya kesalahan nyata dari hukum atau fakta tidak dapat menjadi dasar pembatalan putusan, karena finalitas dari putusan merupakan hal yang penting daripada kebenaran hukum dari putusan tersebut. ICSID menyatakan memiliki kewenangan karena klausul MFN tersebut tidak melarang dengan tegas tindakan pengabaian yurisdiksi pengadilan, sehingga tidak dilarang berarti boleh. ${ }^{23}$ Dengan demikian, tidak terdapat alasan pembatalan putusan ICSID yang memenuhi ketentuan Article 52 Konvensi ICSID, sehingga permohonan pembatalan putusan tersebut harus ditolak.

Dari pertimbangan putusan ICSID tersebut dapat diketahui bahwa alasan-alasan dalam Article 52 merupakan satu-satunya alasan yang dapat digunakan sebagai dasar pembatalan putusan arbitrase ICSID.Alasan di luar ketentuan tersebut tidak dapat digunakan sebagai alasan untuk membatalkan putusan arbitrase ICSID.Sehingga terlihat jelas bahwa alasan pembatalan putusan arbitrase ICSID bersifat limitatif, yakni terbatas pada alasan-alasan dalam Article 52 Konvensi ICSID.

Selain itu, hukum arbitrase nasional beberapa negara juga telah mengakomodir prinsip pembatasan putusan arbitrase, antara lain Hukum Arbitrase Perancis “decree No. 2011-48 of 13 January 2011" dalam Article 1520 menyatakan bahwa,

An award may only be set aside where: 1) the arbitral tribunal wrongly upheld or declined jurisdiction; or 2) the arbitral tribunal was not properly constituted; or 3) the arbitral tribunal ruled without complying with the mandate conferred upon it; or 4) due process was violated; or 5) recognition or enforcement of the award is contrary to international public policy. (cetak tebal oleh penulis)

Kata 'only' memiliki arti 'with no other or others of the same group', ${ }^{24}$ sehingga kata 'only' menunjukkan sifat limitatif dari alasan pembatalan putusan arbitrase. Penggunaan kata 'only' juga dapat ditemui dalam Article 1065 Hukum Arbitrase Belanda "Arbitration Act 1 December 1986 Code of Civil Procedure", yang menyatakan bahwa,

Setting aside of the award can take place only on one or more of the following grounds:

a) absence of a valid arbitration agreement; b) the arbitral tribunal was constituted

22 Ibid, h. 118

23 Ibid, h. 136-137.

24 A.S. Hornby, Oxford Advanced Leaner's Dictionary Fifth Edition, Oxford: Oxford University Press, 1995, h. 810. 
in violation of the rules applicable thereto; c) the arbitral tribunal has not complied with its mandate; d) the award is not signed or does not contain reasons in accordance with the provisions of article 1057; e) the award, or the manner in which it was made, violates public policy or good morals. (cetak tebal oleh penulis)

Penerapan prinsip limitif tersebut dapat ditemui dalam putusan Hoge Raad dalam perkara Eco Swiss v. Benetton International ${ }^{25}$ yang salah satu pertimbangannya menyatakan bahwa, "It is in the interest of efficient arbitration proceedings that review of arbitration awards should be limited in scope and that annulment of or refusal to recognize an award should be possible only in exceptional circumstances." ${ }^{26}$ (cetak tebal oleh penulis)Dengan demikian, maka hanya alasan-alasan tertentu saja yang diakui sebagai alasan pembatalan putusan arbitrase di Belanda, yakni alasan-alasan yang diatur dalam Article 1065 Arbitration Act 1 December 1986 Code of Civil Procedure.

Selain itu, Hukum Arbitrase Singapura "Arbitration Act" dan Hukum Arbitrase Jerman "German Arbitration Law 1998", yang memiliki ketentuan identik dengan ketentuan UNCITRAL Model Law dengan beberapa modifikasi, juga menerapkan prinsip pembatasan alasan pembatalan putusan arbitrase, serta masih terdapat beberapa hukum arbitrase negara lain yang juga menerapkan prinsip tersebut.

Berdasarkan keseluruhan penjabaran di atas, dapat disimpulkan bahwa prinsip pembatasan alasan pembatalan putusan arbitrase telah diterima secara universal dan diterapkan secara konsisten oleh negara-negara.Pembatasan alasan pembatalan putusan arbitrase merupakan implementasi dari sifat less intervention of state dalam penyelesaian sengketa melalui arbitrase, dimana pengadilan harus sedapat mungkin tidak mencampuri sengketa yang para pihaknya telah terikat pada perjanjian arbitrase, termasuk dalam pembatalan putusan arbitrase. ${ }^{27}$

Prinsip pembatasan alasan pembatalan putusan arbitrase tersebut juga telah diakomodir dalam Hukum Arbitrase Indonesia, khususnya Pasal 70 UU No. 30/1999, dan telah diimplementasikan dalam sebagian besar putusan Mahkamah Agung yang secara konsisten menyatakan sifat imitatif dari ketentuan Pasal 70 UU No. 30/1999. ${ }^{28}$

Pertimbangan Mahkamah Agung dalam perkara antara PT. Comarindo Expres Tama Tour \& Travel melawan Yemen Airways ${ }^{29}$ terhadap ketentuan Pasal 70 UU No. 30/1999 dengan mendasarkan diri pada rumusan Penjelasan Umum Alenia ke-18 UU No. 30/1999 yang menggunakan frasa "antara lain" sebelum menyebutkan alasan-alasan pembatalan putusan arbitrase, sehingga menghasilkan interpretasi bahwa alasan-alasan pembatalan putusan arbitrase tidak bersifat limitatif, telah bertolak belakang dengan prinsip yang dianut secara universal dalam praktik arbitrase modern, yakni prinsip pembatasan alasan-alasan pembatalan putusan arbitrase oleh undang-undang.

25 Eco Swiss v. Benetton International, Hoge Raad, Case C-126/97, 1 Juni 1999.

26 Ibid, h. 35.

27 Pasal 3 dan Pasal 11 Undang-Undang Nomor 30 Tahun 1999 tentang Arbitrase (Lembaran Negara Republik Indonesia Tahun 1999 Nomor 138, Tambahan Lembaran Negara Republik Indonesia Nomor 3872).

28 Lihat: Supra, h. 5-11.

29 Lihat: Supranote 2. 
Keberadaan Putusan Mahkamah Agung dalam perkara PT. Comarindo Expres Tama Tour \& Travel melawan Yemen Airways, secara tidak langsung telah memberi preseden terhadap putusan-putusan Mahkamah Agung dalam perkara yang identik di masa yang akan datang. Bahkan saat ini telah banyak advokat praktik yang mendalilkan Putusan Mahkamah Agung dalam perkara antara PT. Comarindo Expres Tama Tour \& Travel melawan Yemen Airwayssebagai dasar permohonan pembatalan putusan arbitrase, antara lain dalam putusan Mahkamah Agung antara PT. Nindya Karya (Persero) dan BANI melawan PT. Tranfocus ${ }^{30}$ dan putusan Mahkamah Agung dalam perkara antara PT. Combined Imperial Pharmaceuticals melawan PT. Parazelsus Indonesia dan $B A N I^{31}$. Kedua putusan tersebut memuat dalil pemohon pembatalan putusan arbitrase yang menyatakan bahwa ketentuan Pasal 70 UU No. 30/1999 tidak bersifat limitatif dengan mendasarkan dalilnya dari pertimbangan hakim dalam putusan Mahkamah Agung dalam perkara antara PT. Comarindo Expres Tama Tour \& Travel melawan Yemen Airways.

Selain itu, dalam praktiknya, Pengadilan Negeri sebagai pengadilan tingkat pertama sebagian besar juga memiliki pemahaman yang identik dengan pertimbangan Mahkamah Agung dalam Putusan antara PT. Comarindo Expres Tama Tour \& Travel melawan Yemen Airways, yakni mendasarkan pertimbangannya pada Penjelasan Umum Alenia ke-18 UU No. 30/1999 untuk melakukan pembatalan putusan arbitrase dengan alasan di luar ketentuan Pasal 70 UU No. 30/1999. Putusan tersebut antara lain: 1) Putusan Pengadilan Negeri Jakarta dalam perkara antara PT Pertamina (Persero) melawan Karaha Bodas Company L.L.C. dan PT PLN (Persero), ${ }^{32}$ di mana Pengadilan Negeri Jakarta Pusat membatalkan putusan arbitrase ad-hoc yang dijatuhkan di Jenewa, Swiss dengan pertimbangan, sesuai dengan alasan permohonan Pemohon, bahwa putusan arbitrase tersebut bertentangan dengan ketertiban umum yang berlaku di Indonesia. Walaupun kemudian Mahkamah Agung dalam tingkat banding membatalkan putusan tersebut ${ }^{33}$; 2) Putusan Pengadilan Negeri Jakarta Pusat dalam perkara antara PT. Hutama Karya (Persero) melawan PT. Bersaudara Simalungun Energi ${ }^{34}$, di mana Pengadilan Negeri Jakarta Pusat mengabulkan permohonan pembatalan putusan arbitrase yang diajukan oleh Pemohon dan membatalkan putusan arbitrase BANI dengan alasan bahwa putusan arbitrase mengabulkan hal yang tidak dituntut dan bertentangan dengan prinsip hukum dan undang-undang. Walaupun kemudian, Mahkamah Agung pada tingkat banding membatalkan putusan Pengadilan Negeri Jakarta Pusat tersebut karena alasan-alasan yang digunakan oleh

30 Putusan Mahkamah Agung Republik Indonesia Nomor 182 K/Pdt.Sus-Arbt/2013 perihal perkara PT. Nindya Karya (Persero) dan BANI melawan PT. Tranfocus, 18 Juli 2013, h. 7.

31 Putusan Mahkamah Agung Republik Indonesia Nomor 893 K/Pdt.Sus/2012 perihal perkara PT. Combined Imperial Pharmaceuticals melawan PT. Parazelsus Indonesia dan BANI, 5 April 2013, h. 15.

32 Putusan Mahkamah Agung Republik Indonesia Nomor 86/Pdt.G/2002/PN.Jktperihal perkara PT Pertamina (Persero) melawan Karaha Bodas Company L.L.C. dan PT PLN (Persero), 27 Agustus 2002.

33 Putusan Mahkamah Agung Republik Indonesia Nomor 01/Banding/Wasit.Int/2002 perihal perkaraPT Pertamina (Persero) melawan Karaha Bodas Company L.L.C. dan PT PLN (Persero), 9 September 2008.

34 Putusan Mahkamah Agung Republik Indonesia Nomor 373/Pdt.G-ARB/2011/PN.Jkt.Pst, perihal perkara PT. Hutama Karya (Persero) melawan PT. Bersaudara Simalungun Energi, 23 Mei 2012. 
Pengadilan Negeri Jakarta Pusat dalam membatalkan putusan arbitrase BANI adalah alasan di luar ketentuan Pasal 70 UU No. 30/1999.

Selain kedua putusan Pengadilan Negeri tersebut di atas, masih terdapat banyak putusan Pengadilan Negeri lainnya yang memiliki kaidah hukum identik, yang menyatakan bahwa berdasarkan Penjelasan Umum Alenia ke-18 UU No. 30/1999, alasan pembatalan putusan arbitrase tidak bersifat limitatif, walaupun putusan Pengadilan Negeri tersebut kemudian dibatalkan oleh Mahkamah Agung pada tingkat banding.

Berkaitan dengan hal tersebut, maka perlu dikaji mengenai fungsi dan kedudukan Penjelasan Umum, khususnya Penjelasan Umum Alenia ke-18 UU No. 30/1999 yang dijadikan dasar pertimbangan Mahkamah Agung dalam Putusan antara PT. Comarindo Expres Tama Tour \& Travel melawan Yemen Airways, dalam suatu peraturan perundang-undangan. Untuk itulah pembahasan selanjutnya akan mengkaji mengenai kedudukan Penjelasan Umum ditinjau dari Hukum Perundang-Undangan.

\section{Analisis Yuridis Penjelasan Umum Alenia ke-18 UU No. 30/1999 yang Digunakan sebagai Dasar Pertimbangan Putusan}

Ketentuan angka 183 Lampiran II Undang-Undang No. 12 Tahun 2011 tentang Pembentukan Peraturan Perundang-Undangan (UU No. 12/2011) menyatakan bahwa, "Penjelasan uтит mетиat uraian secara sistematis mengenai latar belakang pemikiran, maksud dan tujuan penyusunan peraturan perundang-undangan yang tercantum secara singkat dalam butir konsiderans, serta asas, tujuan atau materi pokok yang terkandung dalam batang tubuh peraturan perundang-undangan." Lebih lanjut, ketentuan angka 176 sampai angka 178 Lampiran II UU No. 12/2011 mengatur bahwa penjelasan tidak dapat digunakan sebagai dasar hukum karena tidak memuat norma, selain itu penjelasan berfungsi sebagai tafsir resmi yang menunjukkan original intend pembentuk undang-undang dan tidak dimaksudkan untuk mencantumkan norma.

Berdasarkan ketentuan tersebut, maka rumusan Penjelasan Umum Alenia ke-18 UU No. 30/1999 yang berpotensi menimbulkan interpretasi bertentangan dengan ketentuan Pasal 70 UU No. 30/1999, dimana norma ${ }^{35}$ dalam Pasal 70 UU No. 30/1999 menghendaki adanya pembatasan terhadap alasan-alasan pembatalan putusan arbitrase, sedangkan Penjelasan Umum Alenia ke-18 memberikan kesempatan bagi pemohon pembatalan putusan arbitrase untuk mengajukan alasan di luar ketentuan Pasal 70 UU No. 30/1999, jelas menunjukkan bahwa rumusan Penjelasan Umum Alenia ke-18 UU No. 30/1999 telah memuat ketentuan terselubung yang berusaha memperluas alasan pembatalan putusan arbitrase. ${ }^{36}$ Hal tersebut jelas bertentangan dengan tujuan penjelasan yang dimaksudkan untuk memperjelas aturan

35 Norma adalah suatu ukuran yang harus dipatuhi oleh seseorang dalam hubungannya dengan sesamanya ataupun dengan lingkungannya. Lihat: Maria Farida Indrati S., Ilmu Perundang-Undangan 1: Jenis, Fungsi dan Materi Muatan, Yogyakarta: Kanisius, 2007, h. 18.

36 Sujayadi, Op.Cit., h. 23. 
sehingga ketentuannya harus konsisten dengan tujuan yang hendak dicapai oleh aturan yang bersangkutan. ${ }^{37}$ Selain itu, rumusan Penjelasan Umum Alenia ke-18 UU No. 30/1999 juga tidak sesuai dengan tata cara dan ketentuan pembentukan peraturan perundang-undangan, khususnya bagian penjelasan, sebagaimana diatur dalam UU No. 12/2011.Oleh karena itu, sepanjang frase "antara lain" dalam Alenia ke-18 Penjelasan Umum UU No. 30/1999 sudah sepatutnya dianggap tidak mengikat menurut hukum. Hal tersebut ditegaskan pula oleh Bagir Manan dan Kuntana Magnar mengemukakan bahwa,

Penjelasan resmi bukan kaidah, karena itu tidak mempunyai kekuatanhukum sebagai kaidah.Para penegak hukum atau pelaksana hukum lainnyadan siapapun juga terikat pada ketentuan dalam batang tubuh undang-undangatau peraturan pemerintah tetapi tidak terikat pada penjelasan.Hakim dapat mengenyampingkan penjelasan resmi dengan menggunakanmetodepenafsiranlain,tapihakimtidakdapatmengenyampingkanketentuan dalam Undang-undang atau Peraturan Pemerintah kecuali dalamkeadaan khusus, misalnya karena alasan bertentangan dengan peraturanperundang-undangan yang lebih tinggi atau penerapan undang-undangtersebut akan menimbulkan ketidakadilan yang mendalam dalammasyarakat. ${ }^{38}$

Keadaan serupa juga pernah terjadi dalam Undang-Undang No. 31 Tahun 1999 jo. Undang-Undang No. 20 Tahun 2001 tentang Pemberantasan Tindak Pidana Korupsi (UU No. 31/1999 jo. UU No. 20/2001), dimana terhadap permasalahan tersebut, Mahkamah Konstitusi dalam Pengujian UU No. 31/1999 tentang Pemberantasan Tindak Pidana Korupsi sebagaimana telah diubah dengan UU No. 20/2001 memutuskan bahwaPenjelasan Pasal 2 ayat (1) UU No. 31/1999 jo. UU No. 20/2001 telah memperluas kategori unsur "melawan hukum" dalam hukum pidana, sehingga kriteria perbuatan melawan hukum dalam hukum perdata seolah-olah dapat diterima menjadi satu ukuran melawan hukum dalam hukum pidana, yakni bukan hanya "melawan hukum formil" melainkan juga "melawan hukum materiil", khususnya "melawan hukum materiil positif". Padahal apa yang dianggap patut dan adil menurut masyarakat akan berbeda-beda dari satu daerah ke daerah lain, sehingga dapat menyebabkan ketidakpastian hukum.Oleh karena itu, Penjelasan Pasal 2 ayat (1) UU No. 31/1999 jo. UU No. 20/2001 tersebut bertentangan dengan Pasal 28D ayat (1) UUD 1945. ${ }^{39}$

Selain itu, Mahkamah Konstitusi dalam Pengujian UU No. 41/1999Tentang Kehutanan ${ }^{40}$ menyatakan bahwa seharusnya rumusan norma diatur dalam batang tubuh. Penjelasan Pasal 5 ayat (1) UU No. 41/1999 memuat norma baru yang berbeda maknanya dengan norma dalam Pasal 5 ayat (1) UU No. 41/1999. Dimana, Mahkamah Konstitusi mengubah makna Pasal 5 ayat (1) UU No. 41/1999 yang menyatakan bahwa, "hutan negara dapat berupa hutan adat" menjadi "hutan hak adalah hutan hak tersendiri dari hutan adat dan

37 B.R. Atre, Legislative Drafting: Principles and Techniques, New Delhi: Universal Law Publishing Co., 2001, h. 68-69.

38 Bagir Manan, Kuntana Magnar, Beberapa Masalah Hukum Tata Negara Indonesia Edisi ke-2, Bandung: Alumni, 1997, h. 114-115.

39 Pengujian UU No. 31/1999 tentang Pemberantasan Tindak Pidana Korupsi sebagaimana diubah dengan UU No. 20/2001, MKRI, No. 003/PUU-VI/2006, 24 Juli 2006, h. 73-76.

40 Pengujian UU No. 41/1999 Tentang Kehutanan, MKRI, No. 35/PUU-X/2012, 16 Mei 2013, h. 180181. 
hutan perseorangan/ badan hukum”. Sehingga, hutan adat termasuk dalam kategori hutan hak, bukan hutan negara. Dengan demikian, rumusan "hutan negara dapat berupa hutan adat" dalam Penjelasan Pasal 5 ayat (1), bertentangan dengan UUD 1945 dan tidak mempunyai kekuatan hukum mengikat. ${ }^{41}$

Dengan demikian, apabila ditinjau dari hukum perundang-undangan, pertimbangan Mahkamah Agung dalam putusan perkara antara PT. Comarindo Expres Tama Tour \& Travel melawan Yemen Airways ${ }^{42}$ yang mendasarkan putusannya dari Penjelasan Umum Alenia ke18 UU No. 30/1999 tidak dapat dibenarkan, karena kedudukan Penjelasan Umum hanyalah pelengkap atau komplimenter batang tubuh. Sehingga, seharusnya Penjelasan Umum tidak boleh berisi norma baru atau ketentuan terselubung yang dapat mengubah substansi norma batang tubuhnya. ${ }^{43}$ Mahkamah Agung seharusnya mendasarkan pertimbangannya dari ketentuan yang terdapat dalam batang tubuh, yakni Pasal 70 UU No. 30/1999 yang mengatur alasan-alasan pembatalan putusan arbitrase secara limitatif, bukan dari ketentuan Penjelasan Umum Alinea ke-18 UU No. 30/1999. Dengan demikian, perbedaan interpretasi Mahkamah Agung terhadap alasan-alasan pembatalan putusan arbitrase tidak akan terjadi.

\section{Kesimpulan}

Praktik arbitrase modern menganut prinsip limitatif terhadap alasan pembatalan putusan arbitrase.Prinsip tersebut juga diadopsi dalam ketentuan Pasal 70 UU No. 30/1999 dan telah diterapkan dalam sebagian besar putusan Mahkamah Agung.Putusan Mahkamah Agung dalam perkaraPT. Comarindo Expres Tama Tour \& Travel melawan Yemen Airways yang pertimbangannya menyatakan bahwa alasan di luar ketentuan Pasal 70 UU No. 30/1999 dapat dijadikan alasan pembatalan putusan arbitrase telah bertentangan dengan prinsip limitatif yang dianut secara universal dalam praktik arbitrase modern.

Penjelasan Umum hanya berkedudukan sebagai pelengkap dari batang tubuh.Penjelasan Umum Alenia ke-18 UU No. 30/1999 yang berisi ketentuan yang bertentangan dengan norma Pasal 70 UU No. 30/1999 sudah sepatutnya tidak mengikat hakim. Sehingga, Mahkamah Agung dalam putusannya mengenai perkara PT. Comarindo Expres Tama Tour \& Travel melawan Yemen Airways ${ }^{44}$ yang mendasarkan pertimbangannya pada Penjelasan Umum Alenia ke-18 UU No. 30/1999 telah salah, karena tidak mengindahkan ketentuan Pasal 70 UU No. 30/1999 dan yurisprudensi Mahkamah Agung dalam perkara identik lainnya yang secara konsisten menyatakan bahwa ketentuan Pasal 70 UU No. 30/1999 bersifat limitatif. Sehingga, seharusnya alasan pembatalan putusan arbitrase di luar alasan-alasan yang disebutkan dalam Pasal 70 UU No. 30/1999, dalam kasus ini alasan bahwa BANI tidak memiliki kompetensi absolut, tidak dapat diterima, dan permohonan pembatalan putusan arbitrase sudah sepatutnya ditolak.

\footnotetext{
41 Sujayadi, Op.Cit., h. 24.

42 Lihat: Supra note 2.

43 Jimly Asshiddiqie, Perihal Undang-Undang, Jakarta :Konstitusi Pers, 2006, h. 195-196.

44 Lihat: Supranote 2.
} 


\section{Daftar Bacaan}

Buku

Asshiddiqie, Jimly, Perihal Undang-Undang, Jakarta: Konstitusi Pers, 2006

Atre, B.R., Legislative Drafting: Principles and Techniques, New Delhi:Universal Law Publishing Co., 2001

Badan Pembinaan Hukum Nasional Departemen Hukum dan HAM, Analisis dan Evaluasi Hukum Penyelesaian Sengketa Melalui Arbitrase (Undang-Undang Nomor 30 Tahun 1999), Badan Pembinaan Hukum Nasional Departemen Hukum dan HAM, Jakarta

Fouchard, P., et.al.,Faouchard, Gaillard, Goldman on International Commercial Arbitration, Netherlands:Kluwer Law International, Dordrecht, 1999

Garner, B. A.,Black’s Law Dictionary, Edisi Kesembilan, West, Thomson Reuters, 2009

Gautama, S., Indonesia dan Konvensi-Konvensi Hukum Perdata Internasional, Bandung:Alumni, 2005.

Hornby, A.S., Oxford Advanced Leaner's Dictionary Fifth Edition, Oxford:Oxford University Press, 1995.

Indrati, M.F., Ilmu Perundang-Undangan 1: Jenis, Fungsi dan Materi Muatan, Yogyakarta:Kanisius, 2007.

Manan, B. dan Kuntana Magnar, Beberapa Masalah Hukum Tata Negara Indonesia Edisi keDua, Bandung:Alumni, 1997

\section{Putusan Pengadilan}

Badan Arbitrase Nasional Indonesia melawan PT Cipta Kridatama dan Bulk Trading, SA, MARI, No. 369 K/Pdt.Sus/2010, 9 Juni 2010.

Eco Swiss v. Benetton International, Hoge Raad, Case C-126/97, 1 Juni 1999.

Impregilo S.p.A. v. Argentine Republic, ICSID, No.ARB/07/17, Decision of the ad hoc Committee on the Application for Annulment, 24 Januari 2014.

Pengujian UU No. 31/1999 tentang Pemberantasan Tindak Pidana Korupsi sebagaimana diubah dengan UU No. 20/2001, MKRI, No. 003/PUU-VI/2006, 24 Juli 2006.

Pengujian UU No. 41/1999 Tentang Kehutanan, MKRI, No. 35/PUU-X/2012, 16 Mei 2013.

PT Aneka Bina Lestari melawan Cristian Handoko, MARI, No. 44 PK/Pdt.Sus/2011, 12 April 2012.

PT Padjajaran Indah Prima melawan PT Pembangunan Perumahan, MARI, No. 729 K/Pdt. Sus/2008, 30 Maret 2009. 
PT Pertamina (Persero) melawan Karaha Bodas Company L.L.C. dan PT PLN (Persero), PN Jakarta Pusat, No. 86/Pdt.G/2002/PN.Jkt, 27 Agustus 2002; PT MARI, No. 01/Banding/ Wasit.Int/2002, 8 Maret 2004;MARI, No. 444 PK/Pdt/2007, 9 September 2008.

PT. Comarindo Expres Tama Tour \& Travel melawan Yemen Airways, MARI, No. 03/Arb. Bt1/2005, 17 Mei 2006.

PT. Combined Imperial Pharmaceuticals melawan PT. Parazelsus Indonesia dan BANI, MARI, No. 893 K/Pdt.Sus/2012, 5 April 2013.

PT. Hutama Karya (Persero) melawan PT. Bersaudara Simalungun Energi, Pengadilan Negeri Jakarta Pusat, No. 373/Pdt.G-ARB/2011/PN.Jkt.Pst, 2 Desember 2011; MARI, No. 146 K/Pdt.Sus/2012, 23 Mei 2012.

PT. Manunggal Engineering melawan Badan Arbitrase Nasional Indonesia (BANI), PT. Multi Adverindo, PT. Geostructure Dynamics, MARI, No. 770 K/Pdt.Sus/2011, 19 Maret 2012.

PT. Nindya Karya (Persero) dan BANI melawan PT. Tranfocus, MARI, No. 182 K/Pdt.SusArbt/2013, 18 Juli 2013 